\title{
A Preliminary Study on Vocabulary Learning Strategies Used by the Students from the Faculty of Accountancy
}

\author{
Surina Nayan and Hariharan N. Krishnasamy
}

\begin{abstract}
Communication is almost important without words. Learners with limited vocabulary face difficulties in conveying their messages to others. Therefore, they should acquire enough words to communicate their ideas in L2. Besides, knowing the right strategies to acquire words is also important to help learners in their study. Because of that, the study aims to unveil the usefulness of vocabulary learning strategies among students from the faculty of Accountancy in a public university in northern Malaysia. 52 participants ( 44 female and 8 male) from this faculty participated in the study. From the total of 52 participants, 30 are from the Diploma in Accountancy and the remaining 22 are the students from Diploma in Accounting Information System. The study focuses on second language vocabulary learning acquisition. Participants were asked to answer questionnaires during normal class time. The questionnaire contains seven questions on vocabulary learning strategies where participants had to choose the four options given from 'very useful' to 'not useful at all' based on their L2 study experience on their $L 2$ vocabulary learning process. The findings show that learners preferred to communicate, read books and listen to English songs in order to acquire vocabulary. In addition, they also acquire vocabulary explicitly from their daily routine activities. These suggest that lecturers should focus more on explicit teaching vocabulary because previous research shows that this strategy helps learners in their vocabulary acquisition.
\end{abstract}

Index Terms-Language learning strategies, vocabulary, vocabulary knowledge, vocabulary learning strategies.

\section{INTRODUCTION}

Previous research and writing on vocabulary over the past two decades has addressed the issues on vocabulary size and growth [1], [2], what it means to know a word [3], [4], degrees of word knowledge [5], [6], sources of vocabulary learning [7], vocabulary assessment [8], [9] and also teaching and learning techniques to support learners' vocabulary growth and development [10]. Having adequate vocabulary in L2 helps learners to convey their messages effectively. Our word knowledge and language skills help us to function in society [11]. Schmitt, Schmitt and Clapham [12] state that, "Vocabulary is an essential building block of language and as such it makes sense to be able to measure learners' knowledge of it." In addition, in order to master a second language, learners need to learn its vocabulary [13]. McCarthy [14] states that, "No matter how well the student learns grammar, no matter how successful the sounds L2 are mastered, without

Manuscript received August 8, 2014; revised February 10, 2015.

Surina Nayan is with Universiti Teknologi MARA Perlis, 02600, Arau, Perlis, Malaysia (e-mail: surinana@ @erlis.uitm.edu.my).

Hariharan N. Krishnasamy is with Universiti Utara Malaysia, 06010 , Sintok, Kedah, Malaysia (e-mail: hn1084@uum.edu.my). words to express a wide range of meanings, communication in an L2 just cannot happen in any meaningful way." Harmer [15] further states, "If language structures make up the skeleton of language, then it is vocabulary that provides the vital organs and flesh."

Learners who have problems in vocabulary may find it hard to progress in their study especially when the subjects they learn are taught using the English medium. In addition, university students need to do a lot of presentations in English. Since vocabulary is not assessed like other English language components like speaking, reading, writing and listening, students find it hard to express their ideas effectively. Vocabulary is taught indirectly to learners and it is assumed that learners' vocabulary expansion will happen when learners practice other language skills. Vocabulary expansion is not ensured through this indirect method of teaching vocabulary [16].

Vocabulary knowledge is multi-faceted. One's knowledge of a word refers to his knowledge of aural and written forms as well as the word meaning (receptive and productive vocabulary). Receptive and productive vocabulary contributes to one's language performance in different ways. For instance, receptive knowledge of vocabulary refers to listening and understanding a word when someone says the word. On the other hand, productive knowledge of vocabulary refers to recalling and using the word either in spoken or written form. Learners should know the form of the word and its grammatical behavior when they use the word productively. In other words, knowing a word means learners should know its pronunciation, meaning, grammar, frequency, connotation, formality, collocations, associations and spelling [17].

In addition, there are a number of questions that need to be addressed when it comes to vocabulary assessment. Those questions according to Read [18] include the following:

1) What is a word?

2) Does vocabulary consist only of single words?

3) What does it mean to know such items like lexical items?

4) What is the nature of the construct that we set out to measure with a vocabulary test?

Learners should also have knowledge on lexical items and be able to use them when they perform certain language tasks. Furthermore, learners with insufficient vocabulary knowledge should also have strategies especially when dealing with communication situations.

In addition, to help learners function well in L2, they need to know strategies that may help them acquire L2 vocabulary. Vocabulary learning strategies stem from language learning strategies. Learning strategies refer to what learners do to achieve their learning tasks. These strategies are used by them when they learn grammar, literature, vocabulary and others. 
According to Xhaferi and Xhaferi [19], shallow and deep strategies are employed by these learners. Learners who skip unknown words are those who employ the shallow strategies. Some examples of shallow strategies are guessing from context and repeating words several times. On the other hand, learners who employ deep strategies tend to learn slowly and this helps them to retain information. These learners employ strategies such as key word method and the usage of dictionary.

Language learning strategies refer to learners' intentional behavior and thought that they employ when learning as to help them understand or remember new information. These intentional behavior and thought include their focus on certain aspects of new information that they discover. Furthermore, they also analyze and organize information during their learning process to increase their comprehension. Their learning is also evaluated to check comprehension and whether further actions are needed to enhance their understanding on new information that they get.

Scholars have attempted to link the concept of language learning strategies to vocabulary learning strategies since most language learning strategies are used for vocabulary learning strategies such as obtaining, storing, retrieving and using information.

\section{LITERATURE REVIEW}

Lai [20] states that, "Words do not exist as isolated items in a language. That is, words are interwoven in a complete system in which knowledge of various levels of a lexical item is required in order to achieve adequate understanding in listening or reading or produce ideas successfully in speaking and writing." Therefore, "Learners need a large vocabulary to function in a second language," [21]. "Vocabulary knowledge enables language use, language use enables the increase of vocabulary knowledge, knowledge of the world enables the increase of vocabulary knowledge and language use and so on," [22].

Previous studies on vocabulary learning strategies discover that learners have positive attitudes towards vocabulary learning and they believe that someone who is proficient in English has good vocabulary [23]. Liu also discovers female learners used more vocabulary learning strategies than male learners. In addition, Zhou [24] in his study on receptive and productive academic vocabulary of 71 Chinese EFL learners finds that these learners of non-English major college students know more academic vocabulary receptively than productively. Receptive vocabulary does not involve its production. In contrast, productive vocabulary requires learners to produce this vocabulary when they write or speak with others. Zhou further states that productive vocabulary is built upon receptive vocabulary knowledge.

Noorizah and Zaini [25] on their study entitled "Exploring the vocabulary learning strategies of EFL learners" to 35 post graduate students at the School of Language Studies and Linguistics, Universiti Kebangsaan Malaysia find that learners used most memorization techniques, dictionary strategies and linguistic clues in their vocabulary learning and they seldom used note taking.

Schmitt and Rae [26] on their study to 600 Japanese respondents from junior high school to adults find that most learners used shallow strategies and they were afraid to try to apply deeper strategies in their vocabulary learning because of their unawareness of the alternative strategies offered to them and also their cultural effects whereby certain strategies were favored. In addition, Tuluhong [27] finds that Malaysian proficient and less proficient Chinese ESL learners use various strategies in learning vocabulary. They used most the metacognitive strategies. These learners used media like the television, newspapers and the internet to help them in their vocabulary learning. Besides, they also used the cognitive and memory strategies, while the least used strategy is the social strategies.

In addition, Ahmad Azman, Rafizah, Mohamad Fadhili, Azaharee and Abdul Rashid [28] on their study to 360 students of semesters 1, 2 and 3 diploma students at a tertiary institution in Malaysia find that respondents have limited number of vocabulary learning strategies when they try to learn English vocabulary. The two preferred strategies are guessing and dictionary strategies and these are considered as passive strategies. The respondents were also reported disliked learning from natural exposure. Other strategies that were preferred by them are rehearsal, note taking, encoding and activation.

Sadaf and Zoya [29] on their study to 46 undergraduates from Aligarh Muslim University in India find that memory strategies were most used by them whereas meta-cognitive strategies were the least used. They adopted Schmitt taxonomy in their study. They concluded their study by giving a suggestion that these learners need to be exposed and trained on vocabulary learning strategies so that they are familiar with those strategies. They also suggested that effective vocabulary teaching and learning should be incorporated in their learning process.

In addition, on their qualitative study of vocabulary learning strategies applied by Iranian undergraduate EFL learners in real learning setting, Mahdi and Reza [30] find that the 238 respondents who were randomly selected as their respondents frequently used memory strategies. On the contrary, cognitive strategies were the least used. They concluded that these learners preferred direct strategies which are simple with lower mental activities required. This is caused by the teacher-centered environment that is adopted in Iran whereby teachers provide all the necessary information needed in learning.

$\mathrm{Wu}$ [31] finds motivation as the main factor that affects learners' vocabulary learning strategies. Family involvement in learners study, as well as years of study also affects learners' vocabulary learning strategies. Besides, results of his study suggests that teachers' encouragement and support is needed to help learners to adopt the most useful and effective vocabulary learning approaches so that they will have high motivation to learn and improve their language performance.

Maki and Chow [32] discover that direct vocabulary learning strategies on reading comprehension on EFL learners help them in their learning. Their study involved direct and controlled groups of learners. Direct group of learners underwent structured reviewing. Besides, teachers also adopted mechanical techniques and repeating strategies to 
develop these students' vocabulary storage in reading comprehension. In class, the teachers explicitly introduced and defined the vocabulary.

\section{TAXONOMY OF VOCABULARY}

Many language researchers have developed taxonomy of language learning strategies. Among them are Oxford [33], Gu and Johnson [34], Schmitt [35] and Nation [36]. Oxford [33] introduced Strategy Inventory of Language Learning (SILL) that includes direct and indirect strategies. Direct strategies comprise of memory strategies, cognitive strategies and compensation strategies. Indirect strategies include meta-cognitive strategies, affective strategies and social strategies.

As for $\mathrm{Gu}$ and Johnson [34], their second language vocabulary strategies include meta-cognitive regulation, guessing strategies, dictionary strategies, memory strategies (rehearsal and encoding) and also activation strategies. Schmitt [35] vocabulary learning strategies are grouped into strategies for the discovery of a new word's meaning and strategies for consolidating a word once it has been encountered. Determination and social strategies are under strategies for the discovery of a new word's meaning. In addition, social, memory, cognitive and meta-cognitive strategies are under the strategies for consolidating a word once it has been encountered.

In addition, Nation [36] proposes the strategies that are classified into three general classes namely 'planning,' 'source' and 'processes.' 'Planning' requires learners to decide on where, how and how often to focus their attention on the vocabulary items. "Source' refers to sources like dictionaries or others that help learners in their vocabulary acquisition and 'Processes' include establishing word knowledge through noticing and generating strategies.

\section{OBJECTIVE OF THE STUDY}

The study aims to unveil the usefulness of vocabulary learning strategies used by the students from the Faculty of Accountancy at a public university in Malaysia.

\section{Methods OF THE STUdY}

Questionnaires containing seven multiple choice questions on strategies used by learners were distributed to learners during their normal class time. The questionnaire is an adapted version of He [37]. The questionnaire on vocabulary learning strategies consists of questions on learners' vocabulary learning through reading, from incidental focus on words, through communication, through transition of word meanings, according to its internal formation and association between letters or letter combinations, learning vocabulary of the same categorization together and also learning vocabulary through listening. Learners were asked to rate each strategy on its usefulness from very useful to not useful at all. Data were analyzed using simple descriptive percentage calculations.

\section{FINDINGS AND DISCUSSION}

The results from the L2 vocabulary learning strategies will be presented descriptively in the percentage form. Table I below shows the results of the strategies used by the respondents in their vocabulary learning strategies.

TABLE I: RESULTS OF THE STRATEGIES USED BY RESPONDENTS

\begin{tabular}{|c|c|c|c|c|}
\hline \multirow{2}{*}{ Strategies } & \multicolumn{4}{|c|}{ Results } \\
\hline & $\mathbf{A}$ & B & C & D \\
\hline $\begin{array}{l}\text { 1.Learning vocabulary } \\
\text { through reading books (using } \\
\text { contextual clues to guess } \\
\text { meanings of words) }\end{array}$ & $42.30 \%$ & $53.85 \%$ & $3.85 \%$ & $0 \%$ \\
\hline $\begin{array}{l}\text { 2.Learning vocabulary in } \\
\text { daily life through incidental } \\
\text { focus on words (eg. learn the } \\
\text { word 'pharmacy' from the } \\
\text { brand of a chemist's shop. }\end{array}$ & $23.08 \%$ & $50 \%$ & $26.92 \%$ & $0 \%$ \\
\hline $\begin{array}{l}\text { 3.Learning vocabulary } \\
\text { through communication ( eg; } \\
\text { communication with } \\
\text { teachers, native speakers of } \\
\text { English) }\end{array}$ & $51.92 \%$ & $42.31 \%$ & $5.77 \%$ & $0 \%$ \\
\hline $\begin{array}{l}\text { 4. Learning vocabulary } \\
\text { through the transitions of } \\
\text { word meanings (eg. 'honey' } \\
\text { may mean substance } \\
\text { produced by bees; used to } \\
\text { address someone that you } \\
\text { like/love) }\end{array}$ & $23.08 \%$ & $44.23 \%$ & $30.77 \%$ & $1.92 \%$ \\
\hline $\begin{array}{l}\text { 5.Learning vocabulary } \\
\text { through its internal formation } \\
\text { and the association between } \\
\text { the letters or letter } \\
\text { combinations (eg; prefixes } \\
\text { and suffixes - accept, } \\
\text { acceptable, unacceptable) }\end{array}$ & $5.77 \%$ & $44.23 \%$ & $46.15 \%$ & $3.85 \%$ \\
\hline $\begin{array}{l}\text { 6.Learning vocabulary of the } \\
\text { same categorization together } \\
\text { (eg; words about vegetables } \\
\text { are learnt together-carrot, } \\
\text { cabbage, celery etc.) }\end{array}$ & $23.08 \%$ & $61.54 \%$ & $15.38 \%$ & $0 \%$ \\
\hline $\begin{array}{l}\text { 7.Learning vocabulary } \\
\text { through listening (eg; } \\
\text { listening to a passage or song } \\
\text { repeatedly) }\end{array}$ & $53.84 \%$ & $34.62 \%$ & $11.54 \%$ & $0 \%$ \\
\hline
\end{tabular}

Key: A = very useful; $\mathrm{B}=$ useful; $\mathrm{C}=$ slightly useful; $\mathrm{D}=$ not useful at all.

From the table, only two learning strategies had the highest percentage of 'very useful' which are learning vocabulary through communication $(51.92 \%)$ and learning vocabulary through listening (53.84\%). Games that involve communication among learners help students to improve vocabulary building skills [38]. In addition, oral story telling helps students acquire vocabulary with or without teachers' explanation of words meaning [39]. On the other hand, 1.92\% of learners found learning vocabulary through transition of word meaning 'not useful at all' and learning vocabulary through its internal formation and the association between the letters or letter combination has $3.85 \%$ of 'not useful at all.' This may be because of the difficulties learners find in using correct prefixes and suffixes and also their inability to think hard on word transitions. 
It can be seen that learners find contextual clues useful $(53.85 \%)$ when they try to find meanings of words from reading texts. $42.30 \%$ find it very useful and $3.85 \%$ think that it is slightly useful. It can be concluded that learners find this strategy helpful to help them further comprehend any passage read. Contextual clues help learners predict meanings of words in several ways [40] that in turn help learners' overall comprehension on what they read. The more clues provided, the easier the guessing will be. Nation as cited in He' s work [37] claims that "Learning from guessing word meanings from context is the most important strategy of all learning vocabulary." Learners also find incidental vocabulary learning helpful. $50 \%$ of them think that it is useful to use this strategy, $23.08 \%$ think that it is very useful and $26.92 \%$ feel that it is slightly useful. Hou and Xie [41] find that the increase in the number of incidental vocabulary strategies is the result of the increase of the vocabulary level. Learners also find that communication with others help them learn vocabulary whereby majority of them $(51.92 \%)$ think that this strategy is very useful.

$1.92 \%$ of learners find learning vocabulary through transitions of word meanings not useful at all and $30.77 \%$ find it slightly useful. Learners also find learning vocabulary through prefixes and suffixes useful (44.23\%). However, $3.85 \%$ of the learners find this strategy as not useful at all. In addition, $61.54 \%$ of learners find learning vocabulary of the same categorization together as useful and $23.08 \%$ find it very useful. It can be concluded that learners are comfortable using this strategy when learning vocabulary. Finally, majority of the learners $(53.84 \%)$ find listening helpful in learning vocabulary and nobody chose 'not useful at all' as the answer. Generation Y learners are gadget savvy, so they do not have any difficulties to download English songs that they like from the internet and they even listen to the songs while walking to classes. By doing so will make them familiar with the words pronunciation and at the same time will expose them to many new English words. Farid and Hassiba [42] on their research findings to the first year students at the University Constantine also reveal that the use of songs is beneficial for learners to learn new vocabulary.

\section{SUGGESTIONS TO FURTHER IMPROVE LEARNERS' VOCABULARY ACQUISITION}

In view of the problems related to vocabulary learning, the findings suggest that lecturers should help learners by previewing reading materials to identify unfamiliar words, so that learners will have the opportunity to list the words and find their meanings in advance. This is because some students are not aware of the many strategies that they can adopt to improve their vocabulary since vocabulary is taught incidentally in class by lecturers. This will further help learners comprehend any reading passage given to them. Moreover, the lecturers should encourage students to have a vocabulary portfolio and this portfolio should be checked and graded by the lecturers.

A student's ability to read and comprehend his/her world in books, activities, communication and listening is enhanced when he/she has active vocabulary lists. Students should also be encouraged to work in groups in discussing certain topics related to the subjects learnt, so that they can help each other to be comfortable with English language. When they are comfortable using English, it will help them expressing ideas in groups and in the end they will acquire a lot of vocabulary that is related to the subjects learnt.

In addition, lecturers should be made aware that there is no right or wrong way to teach vocabulary. For pre-intermediate level of students, it is suggested that direct vocabulary learning strategies be implemented. This is because this strategy is easy to be applied and suitable in the beginning stages of developing vocabulary for EFL learners [32].

In conclusion, the best practice to teach vocabulary in any situation will again depend on the classroom environment, learners' family and educational background, the school system and curriculum and also other factors such as learners' accessibility to the internet and peer cooperation. Better facilities without lecturers' knowledge on how to use materials provided to them to enhance their teaching such as videos will not help learners acquire enough vocabulary needed in their learning as well as to function well in community using L2. In addition, educated parents who can guide their children in learning can also help them. Conducive learning environment with comfortable rooms and better equipment and facilities like the internet and television will also contribute to learners' success in vocabulary acquisition and also their L2 learning. Therefore, all these factors do play significant roles in helping learners acquire knowledge needed so that they will become better L2 learners.

\section{REFERENCES}

[1] L. Bhatia, "The developmant of active and passive vocabulary in a second langugage: Same or different," Applied Linguistics, vol. 19, no. 2, pp. 255-271, 1998.

[2] Z. Shen, "The roles of depth and breath of vocabulary knowledge in EFL reading performance," Asian Social Science, vol. 4, no. 12, pp. 135-137, 2008.

[3] P. Nation, Learning Vocabulary in Another Language, Cambridge: Cambridge University Press, 2001.

[4] N. Schmitt, Vocabulary in Language Teaching, Cambridge: Language Education, 2000.

[5] L. Bhatia and Z. Goldstein, "Testing vocabulary knowledge: Size, strength and computer adaptiveness," Language Learning, vol. 54, no. 3, pp. 399-436, 2004.

[6] K. R. Tannenbaum, J. K. Torgesen, and R. K. Wagner, "Relationship between word knowledge and reading comprehension in Third-Grade children," Scientific Studies of Reading, vol. 10, no. 4, pp. 381-398, 2006.

[7] R. Oxford and D. Crookall, "Vocabulary learning: A critical analysis of techniques," TESL Canada Journal, vol. 7, no. 2, pp. 9-30, 1990.

[8] T. Cobb, "One size fits all? Francophone learners and English vocabulary tests," Canadian Modern Language Review, vol. 57, no. 2, pp. 295-324, 2000.

[9] C. Coombe, "Assessing vocabulary in the classroom," in Fundamentals of Language Assessment: A Practical Guide for Teachers, 2nd ed. C. P. Davidson \& D. Lloyd, Eds. UAE: Dubai TESOL Arabia Publications, 2009, pp. 175-190.

[10] J. M. Harmon, W. B. Hedrick, and K. D.Wood, "Research on vocabulary instruction in the content areas: implications for struggling," Readers Reading \& Writing Quarterly, vol. 21, pp. 261-280, 2005.

[11] J. J. Pikuski and S. Templeton. (2004). Teaching and developing vocabulary: Key to long-term reading success. [Online]. Available: www.eduplace.com

[12] N. Schmitt, D. Schmitt, and C. Clapham, "Developing and exploring the behaviour of two new versions of the vocabulary levels test," Language Testing, vol. 18, no. 1, pp. 55-88, 2001. 
[13] N. Schmitt, "Review article: Instructed second language vocabulary learning," Language Teaching Research, vol. 12, no. 3, pp. 329-363, 2008.

[14] M. McCarthy, Vocabulary, Oxford: Oxford University Press, 1990, pp VII.

[15] J. Harmer, The Practice of English Language Teaching, New York: Longman, 1991, p. 53.

[16] S. Moras. (2001). Teaching vocabulary to advanced students: A lexical approach in Karen's linguistics issues. [Online]. Available: http://www3.telus.net/linguisticsissues/teachingvocabulary.html

[17] D. Schmitt. (2010). Are learners getting the knowledge they need? Pearson Education Ltd. [Online]. Available: http://www.pearsonlongman.com/newtotalenglish/pdfs/vocab_trainer. pdf

[18] J. Read, Assessing Vocabulary, J. C. Alderson and L. F. Bachman, Eds United Kingdom, 2000, pp. 16-17.

[19] B. Xhaferi and G. Xhafer, "Vocabulary learning strategies used by students at SEEU in terms of gender and teachers' attitudes towards teaching vocabulary," Research Project, SEEU, Tetovo, Macedonia, $\mathrm{p}$. 119 , November 2008.

[20] Y. L. Lai, "Teaching vocabulary learning strategies: Awareness, beliefs and practices. A survey of Taiwanese EFL senior high school teachers," Master thesis, Department of language and Linguistics, University of Essex, 2005.

[21] N. Schmitt, "Key issues in teaching and learning vocabulary. Insights into non-native vocabulary teaching and learning," ELT Journal, pp. 274-277, 2010.

[22] P. Nation and R. Waring, "Vocabulary size, text coverage and word lists," in Vocabulary: Description, Acquisition and Pedagogy, N. Schmitt and M. McCarthy, Eds. UK: Cambridge University Press, 2001.

[23] Z. L. Liu., "A study on English vocabulary learning strategies for non-English majors in independent college," Cross Cultural Communication, vol. 6, no. 4, pp. 152-164, 2010.

[24] S. Zhou, "Comparing receptive and productive academic vocabulary knowledge of Chinese EFL learners," Asian Social Science, vol. 6, no. 10, pp. 14-19, 2010.

[25] S. H. Ting, M. Mahadhir, and S. L. Chang, "Language and culture: Creating and fostering global communities," in Proc. 2009 7th International Conference of SoLLsINTEC, School of Language Studies \& Linguistics, Faculty of Social Sciences and Humanities, UKM, Malaysia, 2009.

[26] N. Schmitt and D. Rae, "Identifying and assessing vocabulary learning strategies," Thai TESOL Bulletin, vol. 5, no. 4, pp. 27-33, 1993.

[27] Tuluhong, "Vocabulary learning strategies of Malaysian Chinese ESL tertiary learners," Master thesis, Universiti Putra Malaysia, 2006.

[28] A. A. Mokhtar, R. M. Rawian, M. F. Yahya, A. Abdullah, and A. R. Mohamed, "Vocabulary learning strategies of adult ESL learners," The English Teacher, vol. XXXVIII, pp. 133-145, 2010.

[29] S. Zarrin and Z. Khan, "A study of vocabulary learning strategies among undergraduate learners of A.M.U.," US-China Foreign Language, vol. 12, no. 1, pp. 75-82, January 2014.

[30] M. Yazdi and R. Kafipour, "A qualitative study of vocabulary learning strategies applied by Iranian undergraduate EFL learners in real learning setting," English Language Teaching; vol. 7, no. 7, pp. 1-7, 2014.
[31] L. F. Wu, "A study of factors affecting college students' use of ESL vocabulary learning strategies," International Journal of Humanities and Social Science, vol. 3, no. 19, pp. 202-208, November 2013.

[32] N. Maki and Chow, "The study of direct vocabulary learning strategies in reading comprehension: The case of Iranian context," Advances in English Linguistics, vol. 2, no. 1, pp. 95-98, 2013.

[33] R. Oxford, Language Learning Strategies: What Every Teacher Should Know, New York, USA: Newbury House, 1990.

[34] G. P. Yongqi and R. K. Johnson, "Vocabulary learning strategies and language learning outcomes," Language Learning, vol. 46, no. 4, pp. 643-679, 1996.

[35] N. Schmitt, "Vocabulary learning strategies," in Vocabulary: Description, acquisition and Pedagogy, N. Schmitt and M. McCarthy, Eds. Cambridge: Cambridge University Press, 1997, pp. 199-228.

[36] P. Nation, "Learning vocabulary in another language," Cambridge: Cambridge University Press, 2001.

[37] Y. He, "A study of L2 vocabulary learning strategies," Thesis, The School of Teacher Education, Kristianstad University, 2010.

[38] N. T. T. Huyen and K. T. T. Nga, "Learning vocabulary through games: The effectiveness of learning vocabulary through games," Asian EFL Journal, vol. 5, no. 4, pp. 1-15, 2003.

[39] W. B. Elley, "Vocabulary acquisition from listening to stories," Reading Quarterly, vol. 24, no. 2, pp. 174-187, 1989.

[40] S. H. Kolahi, A. Azam, and M. Kehtari, "the comparative effect of types of contextual clues on iranian efl learners' prediction of the meaning of unknown vocabularies," American Journal of Educational Research, vol. 1, no. 8, pp. 272-278, 2013.

[41] S. Hou and H. Xie, "Incidental vocabulary learning of non-English major graduates," The Journal of ASIA TEFL, vol. 4, no. 4, pp. 111-132, 2007.

[42] B. Farid and B. Hassiba, "The efficiency of using songs to learn vocabulary. The case of $1^{\text {st }}$ year students, University of Constantine," Research Proposal for the Partial Fulfillment of a Master Degree in Applied Language Studies, 2010-2011.

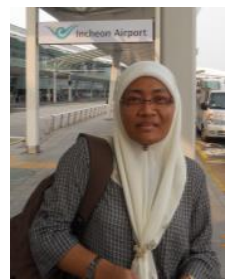

Surina Nayan has a diploma in banking from UiTM, a bachelor degree of science in business (marketing) from Oklahoma State University, Stillwater, USA, and a post graduate diploma in TESL from UiTM and a MA degree in linguistics and English language studies from Universiti Sains Malaysia. Her research interests are on collaborative teaching and learning, second language learning and higher education. She is a member of ASIA TEFL.

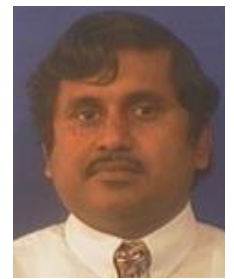

Hariharan N. Krishnasamy has been with the Universiti Utara Malaysia since 1994. Currently, he teaches sociolinguistics and ESP courses. His research interests include intercultural communication, higher education and teacher education. Dr. Hariharan has presented in conferences and published papers on his field and also supervises local and international students. 